search, integrated assessment of the lands state of the annexed territories and the corresponding cartographic support to maintain further socio-economic development of the area. In the same 2011, at Lomonosov Moscow State University, MSU Geoportal started working as a new instrument of collective access and processing of spatial data to provide innovative research and educational activities with relevant materials of remote sensing data of the Earth and analytical tools for conducting geographic data analysis in the Geoportal environment.

Cartographic support of the "New Moscow» project has been realized by means of collection, processing and systematization of geo-spatial data, formation of a geo-data bank and a series of thematic maps, created on its basis. It has been decided to develop Web GIS software by creating a geo-resource on the existed MSU Geoportal, which main purpose is forming the information and cartographic support for the New Moscow territories, based on the profound study of different components of the environment and affecting factors.

The realization of this project has required the creation of a few dozens of maps for the comprehensive ecological and geographical assessment of the lands of the new annexed territories because of their status, economic and socio-geographical state changes.

Key words: ecological and geographical mapping, the concept of a series of maps, geodatabase, data visualization, information resources, geoportal technologies.

Acknowledgement. The study was supported by Russian Foundation for Basic Research and Russian Geographical Society (project №13-05-41233).

\title{
REFERENCES
}

1. Geojekologicheskie problemy Novoj Moskvy: Sbornik nauchnyh trudov / otv. red. Koshkarev A.V., Lihacheva Je.A, Tishkov A.A. [Geoecological problems of New Moscow] - M.: Media-PRESS. - 2013. - 120 p. (in Russian).

2. Kravcova V.I., Erlich V.A. Kartografirovanie struktury zastrojki territorij, prisoedinjaemyh $\mathrm{k}$ Moskve [Mapping the structure of the development of territories, annexed to Moscow] - Geodesy and cartography, 2013. № 6. Pp. 23-32 (in Russian).

3. Lurie I.K. Integracija metodov i tehnologij kartografii, geoinformatiki i ajerokosmicheskogo zondirovanija v geograficheskom kartografirovanii: koncepcii i ih realizacija // Sovremennaja geograficheskaja kartografija / pod red. I.K. Lurie, V.I. Kravcovoj. [ The integration of methods and techniques of cartography, geoinformatics and remote sensing in geographical mapping: concepts and their implementation] - M.: Data+, 2012. Pp. 8-20. (in Russian).

4. Lurie I.K., Baldina E.A., Prasolova A.I., Prohorova E.A., Semin V.N., Chistov S.V. Serija kart jekologo-geograficheskoj ocenki zemel'nyh resursov territorii Novoj Moskvy. [A series of maps of the environmental-geographical assessment of land resources of the New Moscow territory]. Vestn. Mosk. un-ta., Ser. geogr., 2015. № 4. Pp. 49-58. (in Russian).

УДК 364, 640, 577

T.A. Vorobyova ${ }^{1}$, N.N. Mogosova ${ }^{2}$

\section{ANALYSIS OF SOCIAL AND ENVIRONMENTAL CONDITIONS FOR THE URBAN PLANNING OF MOSCOW}

\footnotetext{
Abstract. Town planning is aimed at improving the quality of life by ensuring the rational use of territories of their socio-economic and natural resources. Solution of environmental problems

${ }^{1}$ M.V. Lomonosov Moscow State University, Faculty of Geography, Department of Environmental Management, Moscow, 119991, Russia, Associate Professor; e-mail: tvorobyova@yandex.ru.

${ }^{2}$ GPBU «Mosecomonitoring», Moscow, 119019, Russia, leading analyst; e-mail: eletto@mail.ru.
} 
associated with the decrease of human impact on the urban environment is a major task of urban planning, which is the basis for a comprehensive environmental assessment of the city.

Key words: city natural management, comprehensive assessment of urban quality, urban ecology, urban planning, GIS.

Introduction. Intensive urban development and economic development lead to functional planning changes in the city. Comprehensive study of the existing use and the ecological state of the urban environment needed for making decision to optimize the urban space. The Study can detect the negative effects of human impact and solve social and economic problems of intra-space. Making cities environmentally healthful places in which to live, work and play is a growing concern throughout the world. The focus of much of this concern is on ways to measure and manage the environmental spill overs of one urban function on other urban activities [Vorobyova T.A, 2006]. Some of the most dangerous and annoying spill overs result from manufacturing activities and transport. These impacts are most acute for residential areas and other environmentally sensitive urban functions. [Urban environmental planning..., 2005] Our study aimed to analyse the ecological state of the natural components of the urban environment, including the pollution of air, soil, water bodies, vegetation and noise exposure. The obtained data were the basis for the creation of an overall assessment of the ecological state of the Southern Administrative District of Moscow.

Material and research methods. The research is based on environmental monitoring data for all natural environments of the city, which include both automated data from the stations of air pollution control and natural sites of permanent observation survey of soil, water bodies and vegetation. This information has been Added to GIS (ArcGis 9.3), which were constructed spatial maps of ecological state of the area (fig. 1). Outdoor air pollution was based on traffic flows and settlement patterns of concentration of harmful substances.

Same since 2010 the Moscow State Budgetary Environmental Institution «Mosecomonitoring» maintains the database of resident's complaints integrated to the environmental GIS of Moscow. The incoming complaints are classified by types. Certain dot layers show resident's complaints on ambient air quality, water pollution, noise discomfort or a set of issues of residents ' concern. The mobile analytical laboratory makes on-site assessment of the situation for each complaint. The data on excess of maximum allowable concentration or standards, if any, enter an attributive table of GIS base layer. During analysis of resident's complaints natural and functional peculiarities of the area is taking into consideration. At that it should be identied a pattern of anthropogenic objects distribution and environmental risk sources in accordance to the applicant's (complainant's) address [Zakharova P.V., 2013].

Geographic information system (GIS) is a one of the up-to-date and the most fast-growing tools for urban environmental research. The main task of the methods of modelling, remote sensing and geo-information technologies is to support urban environment quality management, especially decision-making process with the aim to enhance environmental safety of the population. Analysis of the current environmental situation along with inferring of cause-efect relations between natural environments, socio-economic conditions and public health depend mostly on informational support [Mogosova N.N, 2013].

The area of the research is located in the south of the city. Due to its social and planning features - high population density, large territory occupied by industrial plants, location between two major highways - this part of city was included in the «zone of development» with purposes of ecological and social infrastructure improvement.

The socio-ecological assessment of the urban area within the developing zone carried out on the ground of the GIS, developed and compiled by the authors.

For the purposes of the detailed study area was developed structure and content of the social and environmental GIS UZR. It includes a database and a set of analytical and synthetic electronic maps to 6 thematic blocks. Each block was divided into subtypes that characterize the functional planning, demographic and ecological characteristics of the territory. The basis for mapping served 
as the «Unified State cartographic basis of Moscow» in the scale of 1:10 000. There were created 40 thematic maps and digital layers 60 on a scale of 1:20 000 to 1:40 000 .

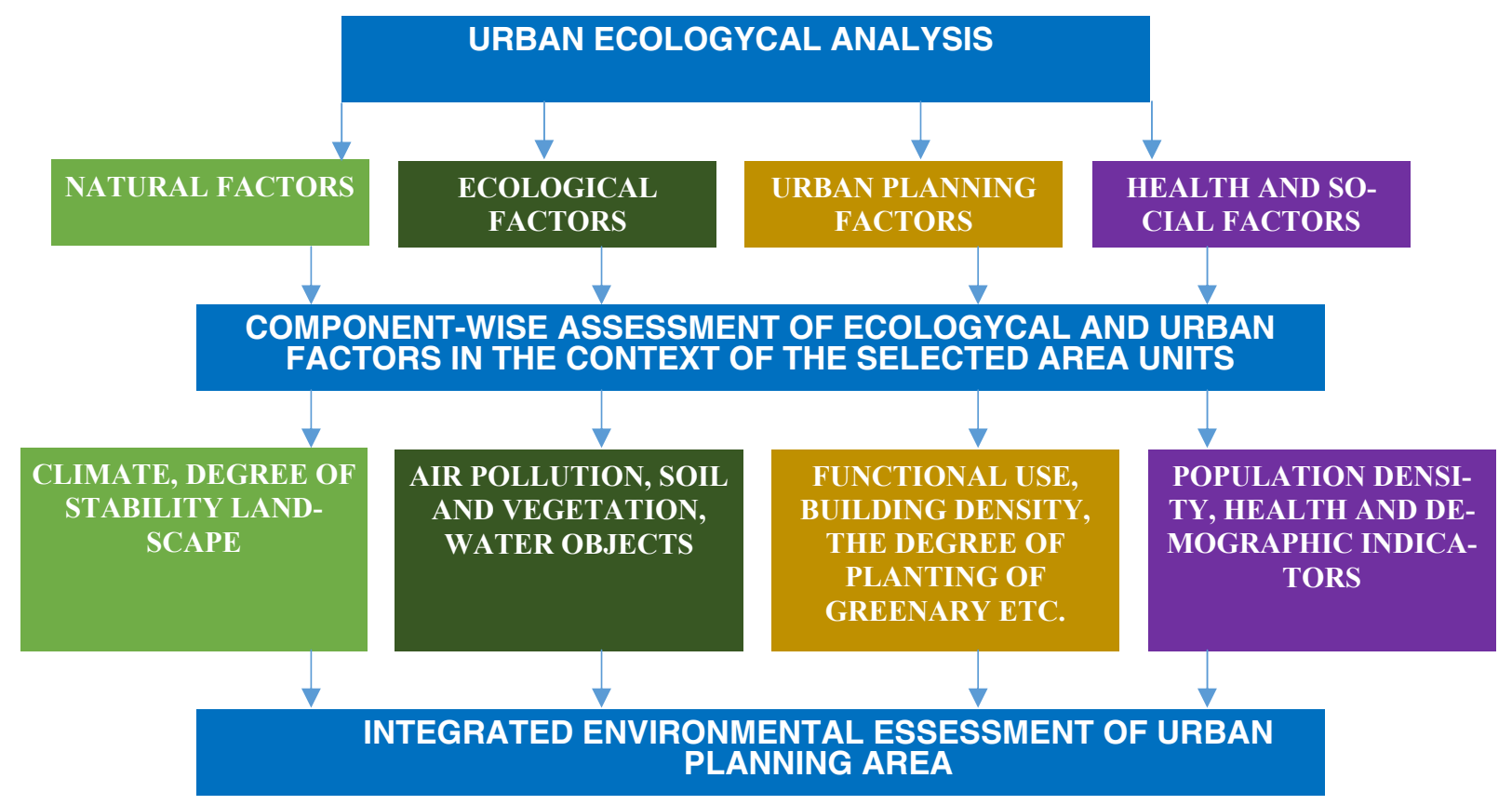

Fig. 1. The structure of the complex environmental assessment of urban area

Socio-environmental analysis of the study area was conducted at 180 sites, which served as the basis for the administrative divisions and functional zoning. Differentiation of the territory on the various living conditions has been completed based on analysis of the ecological and social infrastructure [Mogosova N.N., Vorobyova T.A, 2014].

Results. Dedicated urban development areas are directed not only to the creation of large public centers, but also to eliminate the unevenness in the distribution of social infrastructure. Objects of social infrastructure of the study area in the form of administrative and business, education and training, trade and domestic, cultural, educational, sports and recreational and therapeutic types account for about $10 \%$ of the total area.

Industrial facilities occupy large areas of about 23\% (930 ha) area. These areas may serve as a source for the development of both social systems, and recreational facilities. The largest area facilities located on the territory of Nagatino Gardeners and Tsaritsyno (about 30\% of the total area). Within the boundaries of sanitary protection zones of some enterprises posted a number of residential areas and areas of protected areas.

As a result of the ranking by summing the scores comprehensive assessment of the social discomfort of the territory was carried out. The greatest social discomfort was detected in the district Nagatino where social standards are not met for most of the studied parameters. According to the severity of social problems can also distinguish the northern part of the district Tsaritsyno and Chertanovo North.

Transport and communication system of the city - one of the main sources of environmental pollution. The peculiarity of its impact is expressed in linear forms, linked to transportation and communications facilities. The impact of transport on the nature manifests it-self mainly in bringing the liquid, solid and gaseous substances with high chemical activity and toxicity, as well as in noise pollution.

The highest density of traffic in there on the main radial highways connecting the centre to peripheral areas. At the Kashira and Warsaw highway of cars reaches 12 thousand per hour. Kashirskoye separated from the Warsaw highway just north of the intersection of Nakhimov Avenue and at a considerable angle in areas to the south and southeast. 
Here MPC short term exceeded 2-3 times of nitrogen dioxide and 3-4 times for carbon monoxide. Moreover, if the nitrogen dioxide concentration in the centre of the intersection are reduced and do not exceed the limit ratios, the carbon monoxide remains on the high level of $1.2 \mathrm{MPCs}$ short term (fig. 2).

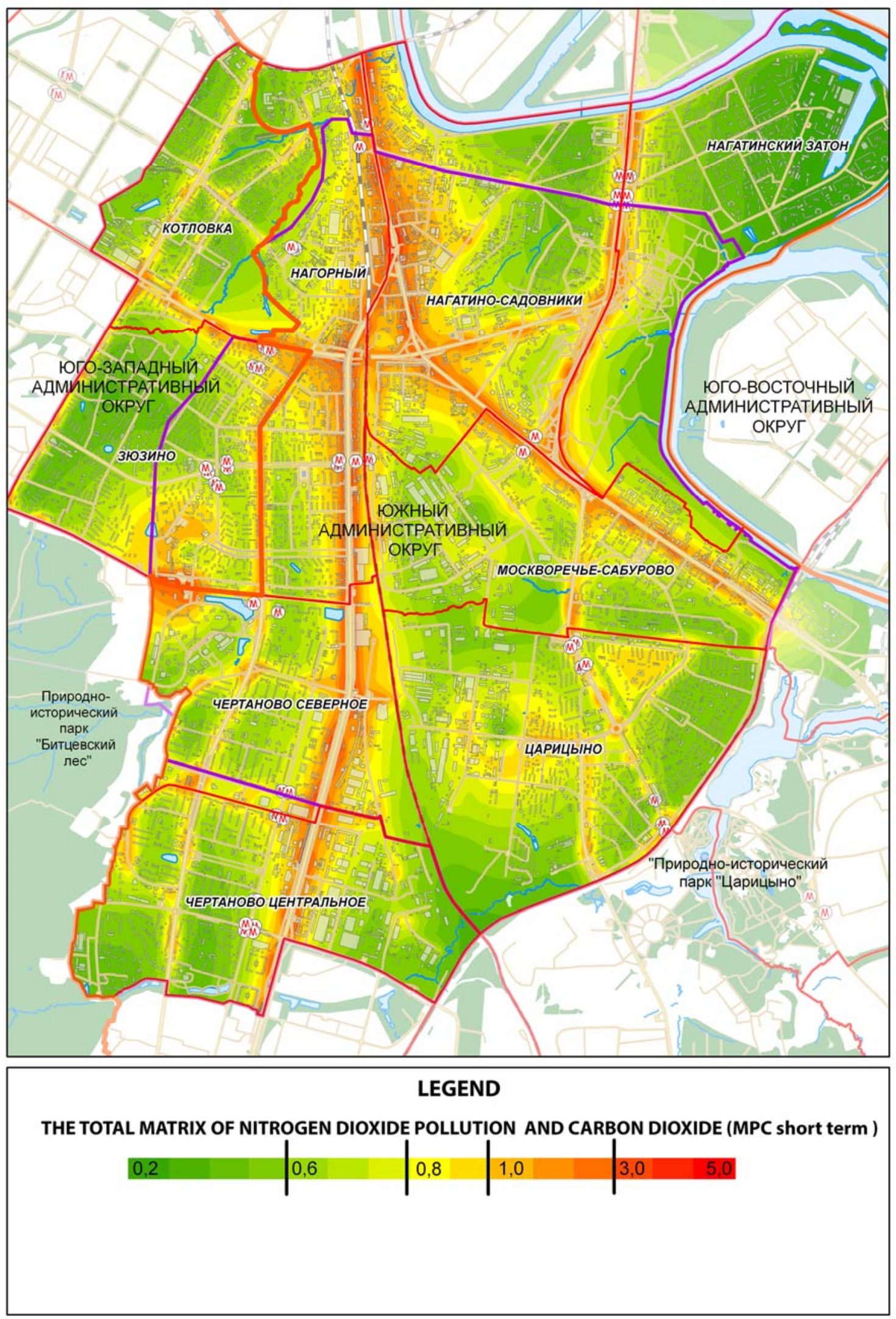

Fig. 2. Air pollution 


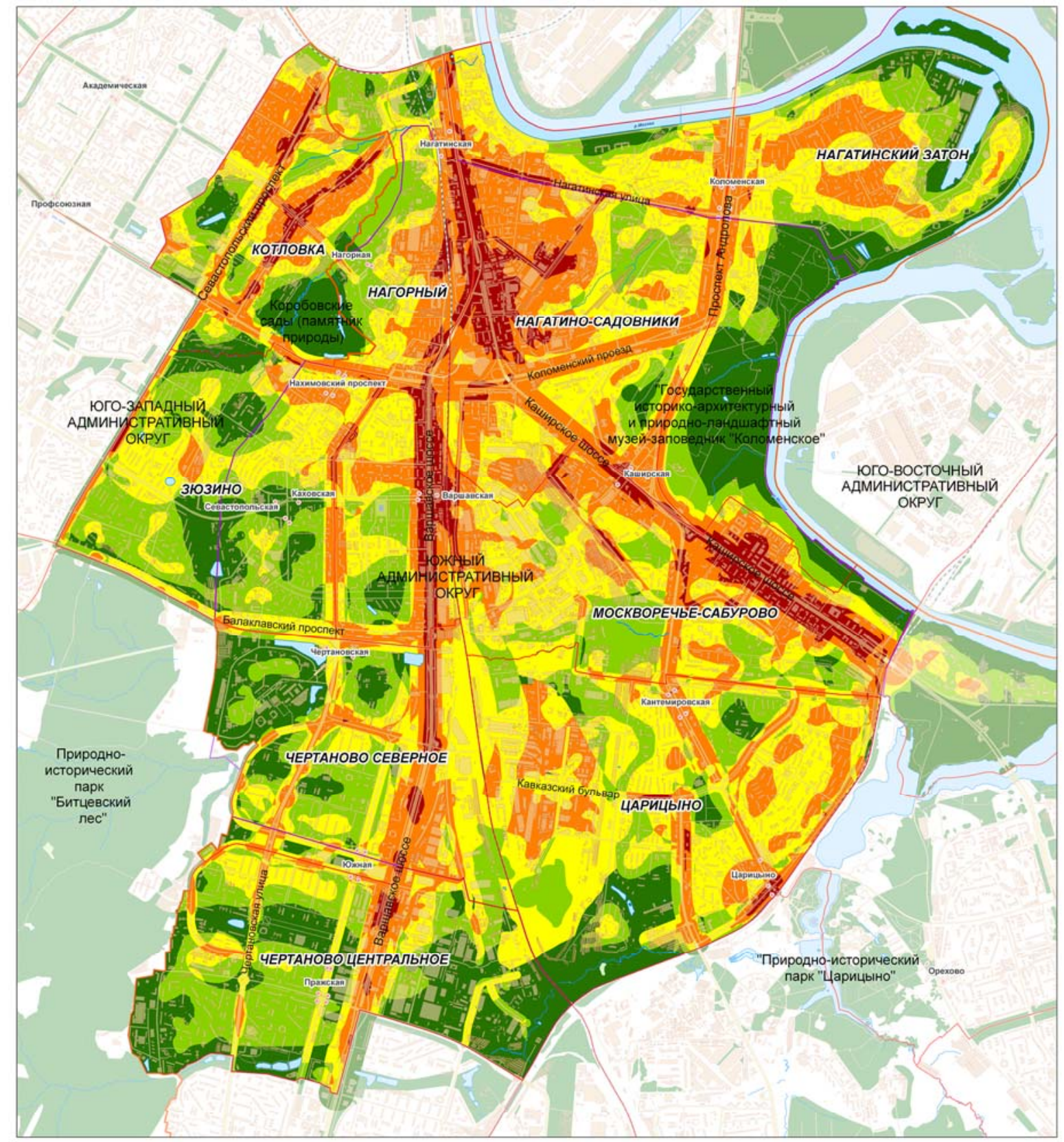

Assessment of current state of the environment

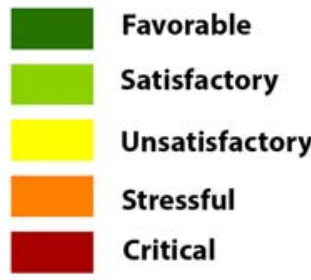

Fig. 3. The complex environmental map of part of South Administrative District of Moscow

The biggest anomaly of soil pollution recorded in the north-western part of the projected area corresponds to the position of 3 industrial zones «Upper boilers», «Nagatino», «Kolomenskoye», an area of over 249 hectares.

A special noise exposure prone areas with the residential area adjacent to the territories in the area of Warsaw and Kashira highway. Here, the distance to the standard levels of noise can be up to 300-400 meters. 
Public areas accounts for only $9.71 \%$ of the total area, while residential areas are located at $31 \%$. A similar imbalance is observed when comparing the recreational areas. Large areas of industrial facilities occupy about $23 \%$. They can partially serve as a source of additional areas for development, as a social and recreational potential.

This evaluation of the state of soil, vegetation, water bodies, noise discomfort and air pollution allowed to allocate 5 gradations of environmental stress on the territory favourable to critical. The critical level of pollution (pollution index of more than 150), apply to industrial sites, located in the northern part of the region. Areas with intense levels of pollution are more differentiated (125 to 150). This is the first residential development sites along major highways (fig. 3).

\section{Conclusion:}

Analysis of synthetic maps created on a comprehensive assessment of the ecological state of the territory and the assessment of the social infrastructure allowed for the differentiation of the territory on the various living conditions. As a result, it was revealed the number of residents living in areas with intense and critical environmental conditions and in conditions of insufficient availability of social infrastructure, which accounted for $25 \%$ of the total population South zone. In satisfactory environmental conditions $23 \%$ of the population lives in poor - about $40 \%$, however, from the perspective of the development of social infrastructure, they can be in different environments - from friendly to the poor. And only $12 \%$ of the population lives in a relatively favourable social and ecological conditions. Improving the quality of living standards due to the formation of the South zone of community centers, resulting in the need to be changes in the structure of the functional zoning. These changes should take place in places of the greatest social and environmental discomfort and be aimed at the reduction and reorganization of the area of industrial zones and creating in their place of public facilities and natural and recreational areas.

Changes in the structure of functional zoning should be held in places of the greatest social discomfort, and should be aimed to reorganization of industrial territories and increasing public facilities and recreational territories.

Residential or public buildings subject to strong anthropogenic pressures need to use a set of measures as landscape planning and managerial issues. Such measures may include the first increase in woody vegetation cover, which creates a natural barrier to contaminants and noise exposure, and increase the level of self-purification of the environment.

Integrated environmental assessment of the urban area is an integral part of urban planning. It allows for the implementation of the master plan of the city in terms of environmental and urban planning requirements with the use of economic, legal and administrative mechanisms, including measures to reduce the impact on the environment, rehabilitation of natural areas thereby positively affecting the quality of life of the population of the city.

Acknowledgement. The studies were conducted with the support of Russian Foundation for Basic Research (project 15-05-01788).

\section{REFERENCES}

1. Mogosova N.N., Vorobyova T.A. A comprehensive assessment of the environmental conditions in urban policy // Engineering for green development. Proceedings of the first RussianJapanese Collaboration Seminar for Sustainable Environment / Ed. by A.A. Пакина. - MSU Publishers, Moscow, 2014. - Pp. 204-209.

2. Mogosova N.N. Assessing the environmental state of the area in a modern city planning. Regional environmental problems. Moscow, 2013. No 2. Pp. 10-20 (in Russian).

3. Urban environmental planning: policies, instruments and methods in an international perspective. 2nd ed (Urban plan- ning and environment) / [edited] by Donald Miller and Gert de Roo, 2005. Pp. 3-4.

4. Vorobyova T.A., Polivanov V.S., Polyakov M.M. Municipal GIS information supply environmental control. Vologda, 2006. 250 p. (in Russian). 
5. Zakharova P.V., Mogosova N.N. Geographic Information tech- nologies in the course of state environmental monitoring in Moscow. The VII International Conference «Remote Sensing the Synergy of High Technologies», Moscow, 2013.

УДК 504.064.2

А.Н. Огурцов ${ }^{1}$, К.А. Бахматова ${ }^{2}$

\section{ИНТЕГРАЛЬНАЯ ОЦЕНКА И ПРОСТРАНСТВЕННЫЙ АНАЛИЗ ПОТЕНЦИАЛЬНОЙ УСТОЙЧИВОСТИ ПОЧВЕННОГО ПОКРОВА УРБАНИЗИРОВАННОЙ ТЕРРИТОРИИ К ЗАГРЯЗНЕНИЮ ТЯЖЕЛЫМИ МЕТАЛЛАМИ}

Резюме. В данной публикации рассматривается интегральный показатель для оценки потенциальной устойчивости городских почв к загрязнению тяжельми металлами, с использованием 10 различных индикаторов устойчивости. Интегральные оченки устойчивости почв получены с использованием АСПИД-метода. Вариант оченочного расчета учитьвал как критерии аккумуляции тяжельх металлов, так и способность почвы к самоочищению. Предлагаемый метод оценки был апробирован на участке в пригородной зоне СанктПетербурга. Пространственный анализ потенциальной устойчивости проводился с использованием географической информационной системы (ГИС).

Ключевые слова: почва, устойчивость, тяжелье металль, интегральный показатель, АСПИД, ГИС.

Введение. Для урбанизированных территорий характерно загрязнение почвенного покрова тяжелыми металлами, распространение которого является крайне неравномерным, отражая распределение техногенной нагрузки на ландшафты в настоящем и прошлом. В связи с высокой плотностью населения на территории Санкт-Петербурга оценка экологической безопасности почв и устойчивости их экологического функционирования приобретает особую значимость.

Закономерности поведения тяжелых металлов (ТМ) в почвах исследуются на протяжении многих лет. Несмотря на сформировавшиеся за это время общие представления о механизмах, ответственных за мобилизацию и закрепление металлов в почве, не хватает точных количественных данных, моделей миграции, исчерпывающе описывающих поведение металлов в почве и взаимодействие с отдельными фазами-носителями.

ТМ перераспределяются в профиле под влиянием процессов почвообразования. Так, оподзоливание приводит к элювиально-иллювиальному перераспределению в профиле не только $\mathrm{Al}$ и $\mathrm{Fe}$, но многих тяжелых металлов ( $\mathrm{Mn}, \mathrm{Cr}, \mathrm{Zn}, \mathrm{Cu}, \mathrm{Ni}, \mathrm{Ce}, \mathrm{La}, \mathrm{Y})$ [Водяницкий, Горячкин, Савичев, 2011]. Поступающие в почву ТМ техногенного происхождения взаимодействуют с различными компонентами почвы. Основную роль здесь играет почвеннопоглощающий комплекс, в состав которого входят минеральные и органические коллоиды. Так, глинистые минералы аккумулируют значительные количества тяжелых металлов [Ильин, 1985, Cances et al., 2003]. Оксиды и гидроксиды железа и марганца формируют пленки на поверхности почвенных частиц, формируют конкреции в почвах. В пленках этих оксидов

${ }^{1}$ Санкт-Петербургский государственный университет, Институт наук о Земле СПбГУ, 199178 , Санкт-Петербург, Россия, инженер-исследователь; e-mail: aogurcov@yandex.ru.

${ }^{2}$ Санкт-Петербургский государственный университет, Институт наук о Земле СПбГУ, кафедры биогеографии и охраны природы, доцент, кандидат с-х н.; Санкт-Петербург, 199178, Россия, e-mail: kbakh@mail.ru. 